\title{
Behavioral ecology of Heteragrion consors Hagen (Odonata, Megapodagrionidae): a shade-seek Atlantic forest damselfly
}

\author{
Geovanni Ribeiro Loiola ${ }^{1} \&$ Paulo De Marco ${ }^{2}$
} ${ }^{1}$ Programa de Pós-Graduação em Ciências Biológicas, Biologia Animal, Universidade Federal do Espírito Santo, Departamento de Ciências Biológicas,
Avenida Marechal Campos 1468, Maruípe, 29040-090 Vitória-ES, Brasil. geovannirl@hotmail.com
${ }^{2}$ Laboratório de Ecologia Teórica e Síntese, Universidade Federal de Goiás, Departamento de Biologia Geral, Instituto de Ciências Biológicas, Rodovia
Goiânia, Campus II, Setor Itatiaia, 74001-970 Goiânia-GO, Brasil. pdemarco@icb.ufg.br

\begin{abstract}
Behavioral ecology of Heteragrion consors Hagen (Odonata: Megapodagrionidae): a shade-seek Atlantic forest damselfly. The intensity of the inter and intra-sexual selection can affect male behavioral traits as territorial fidelity and aggressiveness allowing the existence of different strategies. However, its differential success could be affected by environmental - as the diel variation in temperature - and physiological constrains - as the variation in thermoregulatory abilities. In this context, we present a behavioral analysis of Heteragrion consors (Zygoptera, Megapodagrionidae) trying to characterize its mating system, diel activity pattern, temporal budget, territoriality and reproductive biology. These data were obtained based on field observations using the focal individual method and mark-recapture techniques in $120 \mathrm{~m}$ of a shaded Atlantic Forest stream in Brazil. The males of this species were territorial, varying in its local fidelity, while the females appear sporadically. Males were perched in the majority of the time, but were also observed in cleaning movements, longitudinal abdominal flexion, wing flexion and sperm transfer during perch. The males presented a perched thermoregulatory behavior related to an exothermic regulation. Foraging and agonistic interactions were rare, but dominate the other behavioral activities. Abdominal movements associated to long lasting copula pointed to the existence of sperm competition in this species. Males performed contact post-copulatory guarding of the females. These observations pointed to a non-resource mating system for this species.
\end{abstract}

KEYWORDS. Mating systems; reproductive biology; temporal budget; thermoregulation; territoriality.

RESUMO. Ecologia comportamental de Heteragrion consors Hagen (Odonata: Megapodagrionidae): uma libélula de áreas sombreadas da Floresta Atlântica. A intensidade de seleção inter e intra-sexual deve afetar características comportamentais dos machos como fidelidade a territórios e agressividade possibilitando a existência de diferentes estratégias. No entanto, seu sucesso diferencial pode ser afetado por restrições ambientais, como a variação da temperatura durante o dia; e fisiológicas, como a capacidade de termoregulação. Neste contexto, apresentamos os resultados de uma análise do comportamento de Heteragrion consors (Zygoptera, Megapodagrionidae) buscando caracterizar seu sistema de acasalamento, padrão de atividade diário, orçamento temporal, territorialidade e biologia reprodutiva. Essas informações foram obtidas por observação em campo a partir do método de indivíduo focal e pela técnica de marcação-recaptura em $120 \mathrm{~m}$ de um riacho predominantemente sombreado de Floresta Atlântica no Brasil. Os machos desta espécie foram territoriais com variação na fidelidade local, enquanto as fêmeas praticaram visitas esporádicas. Machos permaneceram pousados durante a maior proporção do tempo, mas foram observados realizando movimentos de limpeza, flexão longitudinal abdominal, flexão alar e transferência espermática durante o pouso. A espécie apresentou comportamento termorregulatório do tipo empoleirador relacionado à regulação exotérmica. Forrageio e interações agonísticas foram raras, mas predominaram sobre as outras atividades comportamentais observadas. Movimentos abdominais associados a uma cópula de duração longa apontam para existência de competição espermática na espécie. Machos forneceram guarda pós-copulatória com contato as fêmeas. Estas observações apontam para um sistema de acasalamento não-baseado em recursos para esta espécie.

PALAVRAS-CHAVE. Biologia reprodutiva; orçamento temporal; sistemas de acasalamento; termoregulação; territorialidade.

In general, small to medium-sized odonates seems to be more sensitive to temperature variation, while larger odonates will be more dependent to solar radiation as a result of the relation of heat acquisition and the surface/volume ratio (May 1991; De Marco \& Resende 2002; Corbet \& May 2008). Odonate thermoregulation is attained through behavioral and physiological responses that affect the metabolic production of heat and heat exchange with the environment. Corbet (1962; but see also a general re-evaluation of the original work by Corbet \& May 2008) classified odonate species into two categories in relation to thermoregulatory behaviors: fliers, expected to be endothermic, can regulate the internal production of heat and use gliding as a heat exchange behavior; and perchers, expected to present different degrees of exothermy, and control body temperature only by body posture adjustments and exposition to solar incidence. Small sized odonates are expected to be thermal conformers that are highly dependent on environment temperature and medium sized to larger exotermic species are usually heliothermic more dependent on solar incidence to attained normal activity (May 1976; De Marco \& Resende 2002). These thermoregulatory constrains may help understand other aspects of odonate biology, especially the territoriality and other aspects of their reproductive biology (De Marco et al. 2005). 
Many odonates are classified as having a resource-defense polyginy mating system (Alcock 1987; DeBano 1993) but it is also known species that present other interesting behaviors, including the recent well demonstrated occurrence of a lek mating system (Cordoba-Aguilar et al. 2009). Emlen \& Oring (1977) noted that if the males could control the access to the oviposition sites by the females they can monopolize mating opportunities. In this context, territorial defense could also enhance the female opportunity to choose among males with different "qualities", usually measured by its ability to maintain a territorial site (Alcock 1979; Fincke 1997). In this system, known as resource-control system (Conrad \& Pritchard 1992), the males defend aggregated oviposition sites and individuals that had morphological or behavioral traits that increase its success in territory acquisition will be favored by sexual selection. In a resource-limitation system, oviposition resources are identifiable in the habitat but it is economically impossible to control its access to the females. In contrast, there are three types of systems were it is not possible to identify clearly oviposition resources: free female choice, female-control and encounter limited system. These models could be distinguished based on rarity and predictability of the male-female encounters.

The variations of mating systems have an obvious effect on the intensity of male-male competition and territoriality. Moreover, it was demonstrated for Libellulid dragonflies (De Marco et al. 2005) a thermoregulatory constraint to the behavioral activities related to territory acquisition. This may suggest that thermoregulatory adaptations may help understand the variations of mating systems and territoriality among odonates, linking these two different subjects. Unfortunately, from 6300 living species belonging to the Odonata, only a small proportion had some useful knowledge about its mating systems and thermoregulatory characteristics, and these informations, when available, had possible bias to temperate species and do not represent the phylogenetic diversity of odonates. Here we present a detailed account of the behavioral ecology and activity pattern of Heteragrion consors Hagen in Selys (Odonata, Megapodagrionidae). The Megapodagrionidae family of the Zygoptera had high specific diversity in the tropics, with the majority of genera at the South America (NoveloGutiérrez 1987). Heteragrion is broadly distributed in South America and exclusively associated to forested streams using wood debris and gravel for oviposition (Machado et al. 1998; Hartung 2002). Our main objective is to characterize its matting system from providing initial descriptions of i) the diel activity pattern; ii) the temporal budget; iii) the reproductive biology; and iv) mating system.

\section{MATERIAL AND METHODS}

We study a population of $H$. consors at the Reserva Biológica de Duas Bocas (RBDB, 20¹8'05"S and $\left.40^{\circ} 28^{\prime} 06^{\prime \prime W}\right)$, Cariacica, Espírito Santo state, Brazil, $27 \mathrm{~km}$ from Vitória and nearly $20 \mathrm{~km}$ of the sea coast. The RBDB is a preserved area of Atlantic forest with 2910ha, in a moun- tain relief with altitude varying from 200 to $800 \mathrm{~m}$, a subhumic climate with the moisture usually higher than $70 \%$, $1500 \mathrm{~mm}$ of average annual rainfall and mean temperature of about $22^{\circ} \mathrm{C}$ (Azevedo \& Santos 2000). The area is mainly occupied by a montane short-heighten tropical forest (Rizzini 1979), with the presence of many important floristic resources that includes the peroba (Aspidosperma, Apocynaceae); macanaíba (Bowdichia, Leguminosae); jacarandá (Dalbergia, Leguminosae); jequitibá (Cariniana, Lecythidaceae) and cedro (Cedrela, Meliaceae). There are also clusters of secondary forests with nearly 50 years of regeneration in areas previously occupied by coffee plantations (Azevedo \& Santos 2000). H. consors individuals were observed in May 2005 in a $120 \mathrm{~m}$ transect in a permanent stream at RDBD. The majority of the stream is bordered by large trees with only small open intervals.

Heteragrion consors is a forest dragonfly present at the core of the Atlantic forest in Brazil (from São Paulo to Bahia states) (Lencioni 2005). They small odonates with $46.2 \mathrm{~mm}$ $(\mathrm{sd}=2.46, \mathrm{n}=30)$ total length and $18.6 \mathrm{~mm}(\mathrm{sd}=1.04, \mathrm{n}=$ 30 ) of left anterior wing length. Male $H$. consors present a dark colored head, thorax with diffuse lateral dark areas, legs with rings yellow and dark and abdomen with the majority of segments dorsally dark (Santos 1970). Females are similar but sexual dimorphism is evident only due to less bright colorations.

We estimated the diel pattern of activity of $H$. consors using the scan method with fixed areas (De Marco 1998; De Marco \& Resende 2002) in 60 segments of $2 \mathrm{~m}^{2}$, in three adjacent reaches, each with 20 samples. In each sampling day the scans were done from 9:00 to 16:00h with 30 minutes intervals. At the end of each interval, the individuals were captured and individually marked with non toxic hydrophobic blackink at the wings and released at the same segment from where it was captured. This technique is widely used in population studies of odonates (Cordoba-Aguilar 1994a; Cordoba-Aguilar 1994b), not causing any harmful effects on its behavior or survival (Norma-Rashid 1999). We measured air temperature in each scan using a mercury thermometer at $1 \mathrm{~m}$ above soil and recorded the direct exposition to sun of each segment during the scan. In each segment we measured stream depth and width with the precision of the nearest $0.5 \mathrm{~cm}$.

In each scan interval a session of 5 minutes was used to quantitative observations of behavior using the focal method (De Marco et al. 2002; Resende \& De Marco 2010). To avoid systematic bias related to the chance of beginning a behavioral session with some behavioral categories (e.g. it is easy to find resting individuals) we discharged the first $1.5 \mathrm{~min}$ utes for the further analysis. The sequence and amount of time spent in each behavioral category was registered with a digital recorder for each observed individual, including information about its unique mark on the wings. The behavioral categories were derived from previous studies (Shelly 1982; De Marco 1998) and included: (i) perching, with the individual remained at the perched or with small movements without leaving the perch; (ii) transition flight, characterized 
by the transition between perches without the interruption of the movement in any aerial point; (iii) foraging flight, which consisted in a short directed flight with the short return to the perch (sometimes it was possible to identify the attacked prey at the mouth of the observed individual, but even when it was not possible the general behavior follow the pattern here described); (iv) agonistic flight, a direct, rectilinear flight or in circles toward to another individual; (v) pre-copula, physical contact among mates prior to copulation; (vi) copulation and (vii) oviposition, with the association between males and females characterizing a post-copulatory guard. Any other behavior observed during the field observations was included in the protocol. Behavioral observation was made exclusively on marked individuals. We measured the height and distance of the perches to margin (with precision to the nearest $0.5 \mathrm{~cm}$ ) used by the focal male during each behavioral observation. Temporal budget and the diel activity pattern in each behavioral category was determined based on proportion of time spent during behavioral analysis.

We also made focal observation of reproductive activity in the majority of cases were couples were observed, following the same general protocol described above, but including some ad libitum observations to provide a general description of the sequence and duration of reproductive activity.

\section{RESULTS}

During the observations, the mean air temperature was near $24.4^{\circ} \mathrm{C}(\mathrm{SD}=1.08 ; \mathrm{n}=601)$ with extremes in $19.7^{\circ} \mathrm{C}$ and $27.3^{\circ} \mathrm{C}$, showing an obvious stable pattern. Four rainy days occurred during this study, but they clearly contributed to the increase in water level and water current of this small stream. Stream width varied from 35 to $335 \mathrm{~cm}$ (mean = 102.5; $\mathrm{SD}=62.85 ; \mathrm{n}=180)$, and depth from 5 to $75 \mathrm{~cm}$ (mean $=10.5 ; \mathrm{SD}=11.09 ; \mathrm{n}=180)$. Only in seven occasions other odonates species was observed (three Libellulidae and four times Hetaerina auripennis), showing that $H$. consors is clearly the dominant species there.

Male activity of $H$. consors increased with air temperature until the mid-day. After this time, air temperature remains relatively constant but male abundance decrease slowly (Fig. 1A). Females were always rarer than males at the stream margin with a much more erratic variation during the day, but with higher abundance after the mid-day and decreasing until de 16:00 h (Fig. 1B).

A total of $16.6 \mathrm{~h}$ of behavioral observation were realized in 70 different individuals represent a total of 974 total sample size for time budget calculations. H. consors spent the majority of its time perched $(97.7 \%$ of total time; $\mathrm{SD}=0.091)$. Perched $H$. consors males exhibit cleaning behaviors (78 events), wing flexion over the longitudinal axis of the body (155 events), sperm transfer (contact of the ninth abdominal segment with the accessory genitals; 17 events) and abdominal undulation (221 events). This last behavior is usually followed by wing rising higher above the thorax ( 71 events). Sperm transfer was done without the presence of any potential female.
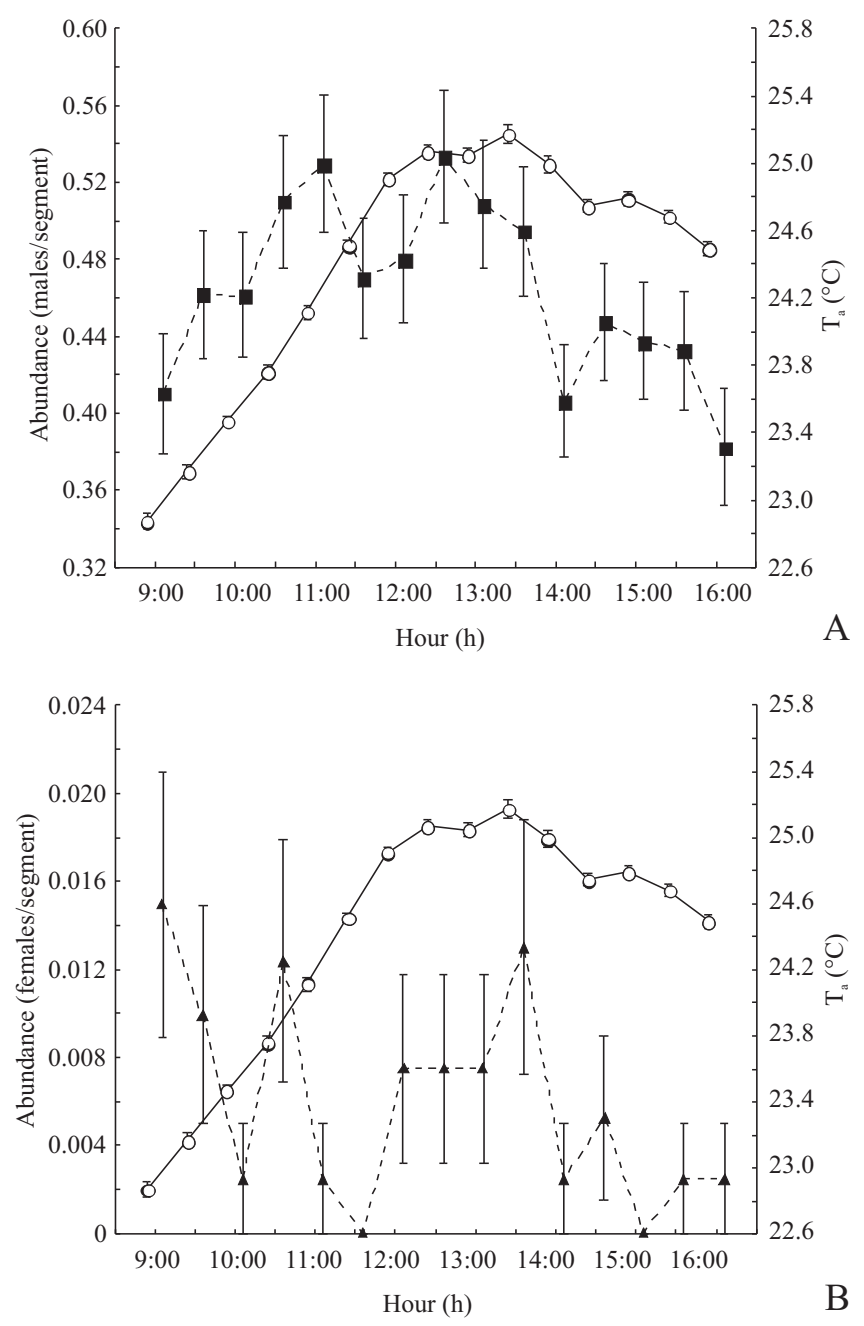

Fig. 1. Diel variation in the abundance of males (ם) (a) and females ( $\mathbf{A})$ (b) of $H$. consors in relation to air temperature $\left(\mathrm{T}_{\mathrm{a}}\right)(\mathrm{O})$. Bars represent standard error in $150 \mathrm{~h}$ and 2814 individual observations.

Foraging and agonistic interactions followed by oviposition dominate the small proportion of other behavioral activities of $H$. consors (Fig. 2). The reproductive activities do not reach $1 \%$ of total time budget and include short time dedicate in copulation and a relative high time spent in female guarding during oviposition. Transition flight occurred for short distances always less than $3 \mathrm{~m}$. Foraging flights included pursue and capture of prey usually less than $2 \mathrm{~mm}$ length, mainly Diptera. Male H. consors perform lateral body movements after abandon the perch, probably related to visual search of potential prey. In 43 different males (420 minutes of observation) we estimate that the mean rate of foraging equals $0.46 \mathrm{flight} / \mathrm{minute}$.

In 50 agonist interactions observed we distinguished linear flights (32 events ranging from 2 to 4 seconds) and circular ascendants flights (18 events from 3 to 24 seconds). These circular flights usually initiate at $0.5 \mathrm{~m}$ over the stream and end at the height of the perch used before the dispute. Both agonistic interactions do not include physical contact and end with one male moving away while the other remains in a nearby perch. 


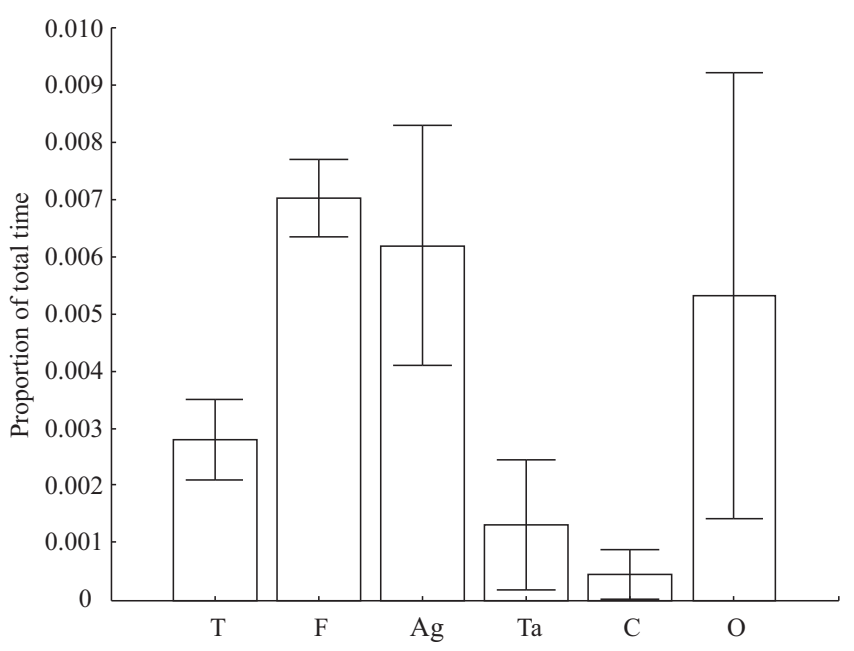

Fig. 2. Time budget analysis for behavioral activities of males of $H$. consors (based in 285 sessions of observation of behavior) discharging perch and including transition $(\mathrm{T})$, foraging $(\mathrm{F})$ and agonistic flights $(\mathrm{Ag})$, tandem $(\mathrm{Ta})$, copulation $(\mathrm{C})$ and oviposition $(\mathrm{O})$. Bars represent the standard error.

Flight activities, in relation to the total time expending in foraging, aerial contests and transition flights are shown in Figure 3. In general, we expect that aerial contests for territorial defense take place after the female arrival at mid-day and foraging occurs in moments of higher abundance of prey or lower territorial and reproductive activity after the 14:00 $\mathrm{h}$ as in other odonates. Nevertheless, $H$. consors do not follow this general pattern. Foraging was the most common event occurs all over the day, while the other activities occurred irregularly but continually from 9:00 to 16:00 h.

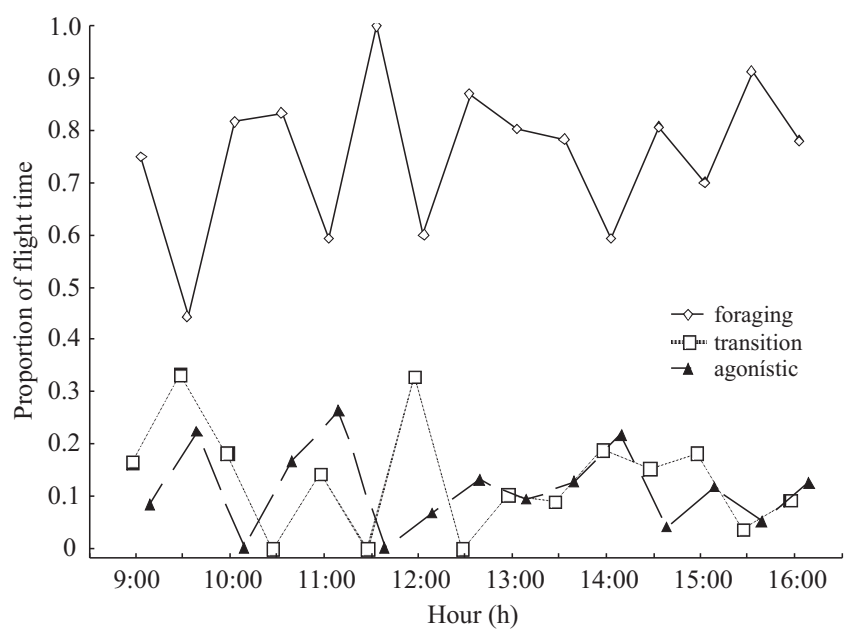

Fig. 3. Diel variation in proportion of time expend in different behavioral categories of males of $H$. consors (based in 285 sessions of observation of behavior) excluding the time expent in perch.

We observed a total of $2.4 \mathrm{~h}$ the total sequence of reproductive behavior in 13 different couples. Each $H$. consors male remained perched while females eventually transit through parallel routes near male's perch. There was no courtship display, and males responded to the presence of the opposite sex by flying to and capturing the female by grasping the female's body with their legs in the air followed by the grasp of the appendages. Mating is occurring throughout the day, but 9 from the 13 observed couples copulated between 10:30 and 13:30 h.

Physical association between male and female, the tandem, had mean duration of 5.2 minutes $(\mathrm{SD}=5.45 ; \mathrm{n}=7)$. The tandem initiates in the air and continue in a nearby perch not necessarily in the male territory. In the perch, the male vibrate its abdomen several times probably stimulating the completion of copulation by the female. The copulation initiate at the perch and last for a mean time of 19 minutes (SD $=2.70 ; \mathrm{n}=5$ ), with strong abdominal movements by the male. This entire process was usually followed by 2 or 3 other males, and sometimes one of them initiates agonistic interaction with the male that was attached to the female. We do not observe any case of interaction with these males that resulted in the termination of copulation or separation of the couple.

After copulation the male remain in tandem guiding the female to oviposition sites located at the margins of the stream. Only in one case the oviposition occurred in the site were the female was captured, otherwise the pain in tandem move for several meters near the water surface before initiates the oviposition. The oviposition sites showed litter accumulations and small roots of terrestrial plants near the margins.

Female $H$. consors apparently probe with the abdomen tip for the existence of submerged litter or dead stems. The oviposition lasts for 11.66 minutes ( $\mathrm{SD}=8.74 ; \mathrm{n}=4)$, with the females ovipositing by abdomen submersion. Males remained attached to the females in sentinel position. This position consists with the male suspended perpendicularly to the female by the abdomen. After several oviposition events, the female was release by the male.

The return to the same perch by $H$. consors males was evident. Based on 105 marked males the mean permanence in the same site is 3.2 consecutive days (ranging from 1 to 20 days). This variation could represent possible differences in male strategy or ability to maintain a territorial spot. Substitution of territorial owner was a rare event and occurred by expulsion, abandon and, probably, by mortality. We observed two couples and two single males captured by spider webs during this study, usually short above the water. We measured the position of 285 perches belonging to 70 marked males. The distribution of perch height is approximately normal with the modal class in 80 to $100 \mathrm{~cm}$ with $20 \%$ of the records (Fig. 4). In 50 agonistic flights observed, the mean perch height was also $100 \mathrm{~cm}(\mathrm{SD}=39.07)$. The distance to the margin of the perches was also in a normal-like shape but with larger tail to the terrestrial side (Fig. 5). Larger frequency of perches occurred from 10 to $70 \mathrm{~cm}$ in the terrestrial direction of the axis. Similarly, from 50 observed agonistic flights the mean distance to water was $44.9 \mathrm{~cm}$ $(\mathrm{SD}=32.5)$ from the margin. There was $6 \%$ higher probability to find an $H$. consors male in a sunny-spot segment 
$(44.1 \%, \mathrm{n}=730)$ than in shaded segments $(38.1 \%, \mathrm{n}=5270)$, and these differences were not explained by chance alone $\left(\chi^{2}=9.678 ; \mathrm{df}=1 ; \mathrm{p}=0.002\right)$. This small difference is expected since the majority of available areas where shaded by forest $(87.8 \%, \mathrm{n}=6000)$.

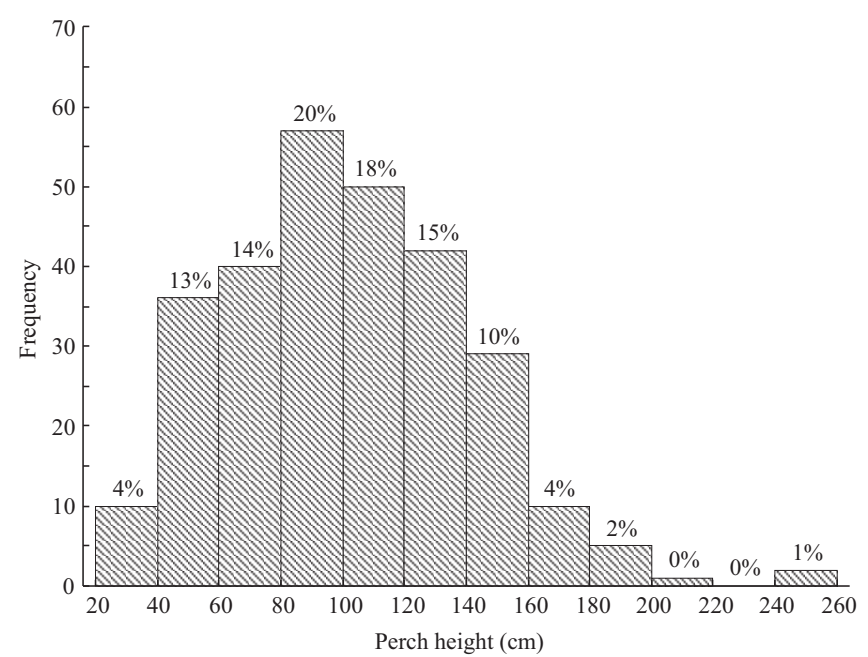

Fig. 4. Distribution of the height of perches used by males of H. consors $(\mathrm{n}=285)$.

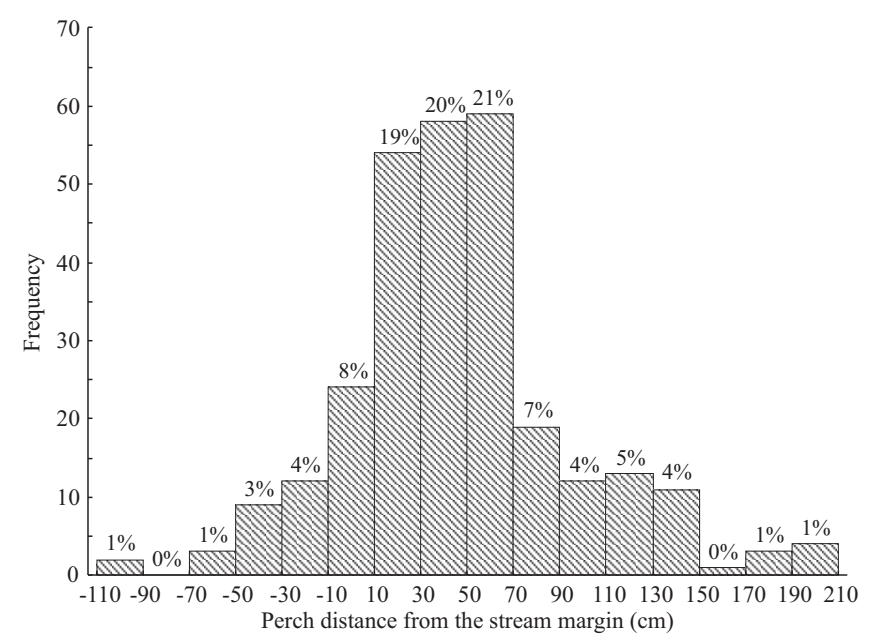

Fig. 5. Distribution of the distance to margin in perches used by males of $H$. consors. Negative values in the abscissa represent perches in the stream surface and positive values perches in the terrestrial margin $(\mathrm{n}=285)$.

\section{DISCUSSION}

Diel variation in abundance of odonates at rendezvous sites are shown to be affected by population density (Meek \& Herman 1990), sexual differences (Norma-Rashid 1999), air temperature (May 1991; Hilfert-Ruppell 1998; De Marco \& Vital 2008) and luminosity (Shelly 1982; De Marco \& Peixoto 2004). H. consors present a higher activity before mid-day, but a stable pattern of abundance during the day with almost 7 hour of activity, probably due to relatively stable air temperatures inside the forest. This day-time period of territorial defense is relatively high, at least when compared to published records of Calopteryx maculata and Hetaerina cruentata (Waage 1979a; Cordoba-Aguilar 1994b).

Abundance of male $H$. consors at water was higher than females as it is expected. Since oviposition does not occur in the male territory, our observations suggest that $H$. consors males defend territories that increase the chance of interception or visualization of a female approaching the stream and/ or increase the efficiency in capture of prey. Nevertheless, there is no clear pattern of arrival to the stream that could be consistent to the hypothesis that territorial males arrive earlier and acquire better sites as is observed in other species (Higashi \& Nomakuchi 1997). Male H. consors appear to increase its presence in territories with the increase of temperature. As H. consors males use shaded habitats, it is possible that the benefits to arrive earlier on territories do not surpass the costs of initiate activity at low air temperature, contrasting with the arguments presented by Conrad \& Pritchard (1990).

There was demonstrated a strong effect of body temperature on maximum lifting force to initiate flight in another Zygoptera species (Samejima \& Tsubaki 2010), relating the costs of territorial defense with thermoregulatory capabilities. Many forest dragonflies may respond to these restrictions choosing sunny spots for territorial defense (Samejima \& Tsubaki 2010; Tsubaki et al. 2010) or by recurrent sunflights (Clausnitzer 1998)for basking near tree-tops. Both of these examples came for species larger than $H$. consors, which do not present any of these behaviors. H. consors males maintain its usual behavioural activities, including territorial defense, in shaded areas probably due to high efficiency in convective heat exchange due to its small size (May 1991).

The time-budget of $H$. consors males support its classification as a percher and an exothermic species. In those species it is expected a close relation between the relative importance of convection and irradiation heat exchange and body size (May 1977; Polcyn 1994; De Marco \& Resende 2002). Small insects are expected to be conformers (relying on convection heat for thermoregulate) and, with the increase of body size, it is expected to found more heliothermic species (increasing the dependency on direct irradiation). $H$. consors had a small size and it is expected that it present a conformer behavior, leaving in shaded habitats. The behavior of perching with open wings, which is shared with other Megapodagrionidae, could represent a possibility to an increase in body surface favoring convective heat exchange. All these interpretations are based on the general thermoregulatory theory of odonates (May 1991; De Marco et al. 2005; Corbet \& May 2008). Unfortunately, most of the general construction of this theory came from data from Anisopterous dragonflies as recently reviewed by Corbet \& May (2008). Otherwise, our data on general behavior, temporal budget and activity pattern of $H$. consors provide a support of those arguments for this Zygopteran group. 
Another aspect of odonate thermoregulation is the ability to absorb heat by cuticle, which is affect by body color (Henwood 1975). The general dark pattern of thorax in $H$. consors could be well adapt to leave in shaded areas increasing its absorbing abilities (Hilfert-Ruppell 1998). These morphological and behavioral characteristics suggest this species as associated to forested streams, and probably a good biological indicator of pristine habitats as other species of this genera (Ferreira-Peruquetti \& De Marco 2002).

Male $H$. consors presented a highly opportunistic foraging behavior. It appear that it take advantage of the presence of small dipteran aggregation over the stream. Foraging through the day could be a problem due to loss of mating opportunities. We expected that natural selection should favor individuals that forage in periods before the time of female arrival (usually near sunset), which maximize foraging and decrease the loss of mating opportunities. As the females appear to arrive erratically around day-time in this $H$. consors population, it is also expected the foraging pattern observed here. Shelly (1982) found a similar pattern in H. erythrogastrum that present a slightly lower foraging rate (0.36 flight/minutes). Both species prefer to forage from shaded perches, but $H$. consors also are observed in partially shaded perches.

The territorial defense of sites near water bodies by male Odonata is a behavior related to increase the chance to acquire and protect a potential mate (Jacobs 1955; Johnson 1964; Corbet 1999). The regular return to the same site and the active exclusion of other males characterize the territoriality in odonates (Gribbin \& Thompson 1991; Resende \& de Marco 2010). Both aspects were observed in H. consors. Territorial defense are expected to result in a high energetic cost (Marden \& Waage 1990), especially in areas with high male density. Nevertheless, the more regular distribution of male $H$. consors in the stream margin, as we had observed, could decrease the time and energetic cost in aerial contests.

Male $H$. consors showed intense aerial contests in the same periods that couples were observed in mating, suggesting that the probability to find mates intensify the agonistic behavior, as described to Hetaerina cruentata (Cordoba-Aguilar 1995). Rectilinear or ascendant aerial contests, as we observed in $H$. consors, are also observed in Calopterygidae (Marden \& Waage 1990) and Libellulidae (Wildermuth 1991; Wildermuth 1994; Irusta \& Araujo 2006). In H. consors, ascendant contests take longer times and is clearly related to other escalated contest that occurs in Calopterygidae damselflies. Waage (1988) demonstrate that escalated contests occurred when a male return from an oviposition (that could take more than 20 minutes) and find an male that during this time had act as owner of the territory. Confusion over which one is the territory owner could produce these escalated contests. In other Megapodagrionidae, $H$. tricellulare and Rhinagrion borneense, frequent territorial contests are prevented by a ritualized display sequence, including the elevation of the shining abdominal extremity (Paulson 1981). Despite the existence of rising abdomen behavior in $H$. consors, we were not able observe a direct relation between this behavior and a "dear enemy" strategy as observed in other territorial defense strategies (Fox \& Baird 1992; Temeles 1994; Pratt \& McLain 2006).

The behavior of abandonment of the territory and the displacement for different oviposition sites reveal three types of costs for males (Alcock 1982; Waage 1988): (i) the incapacity to capture and to copulate with females that attend in his territory during his absence, (ii) the possible loss of the territorial ownership for another male and (iii) escalated contests with other males. However, the daily probability of a female $H$. consors to appear along the stream margin was relatively low (2.14 matings/day; $\mathrm{n}=16$; ranging from 1 to 3 ). Males of Hetaerina vulnerata present a relationship still lower, exhibiting only 0.3 matings/day (Alcock 1982). The males of this species also accompany its female during oviposition, but the female is completely submerged while ovipositing, a behavior that eliminates the need of post-copulatory mate guarding. In contrast, males of C. maculata do not abandon their territories and consequently they do not accompany their partners to new oviposition sites (Alcock 1979; Waage 1979a). The post-copulatory contact-guarding of females seems also to be unnecessary in this species, because their females oviposit in plant resources in the male territory. The great contrast among these species is that $C$. maculata exhibits the higher average female encounter rate (4.7 matings/day, Waage 1979a). Therefore, under lower rates of female arrival in $H$. consors and Hetaerina vulnerata it is not expected a strong selection that favors choice of a territorial site that include position resources, or at least minimize the cost associate to be unable to identify possible oviposition resources. Our observations suggests that $H$. consors male (as also occurs in Hetaerina, Alcock 1987) are not able to identify oviposition resources due to submerged oviposition behavior of the females.

As is common for many odonates (Miller et al. 1984; Corbet 1999), pre-copulatory tandem is rarely broken by the females, possibly due to high energy costs. This general pattern is followed in $H$. consors and none observed females resisted to capture or was released after the copulation and oviposition. Nevertheless, the pre-copulatory tandem may be especially adaptive to species as $H$. consors whom females are extremely rare.

Females of Odonata can copulate with several different males, and in some species, the male can re-locate or remove the sperm of the previous copulation (Waage 1979a; Higashi \& Nomakuchi 1997; Hayashi \& Tsuchiya 2005). Sperm competition in those species may be an important component of male fitness and may result in long copulations (Waage 1986; Siva-Jothy 1987; but see Cordoba-Aguilar 2001). Intense abdominal movements are probably related to sperm removal (Waage 1979b) and are also observed in the long lasting copulations of $H$. consors, supporting the possible existence of sperm competition in this species.

Post-copulatory guarding of mates reduces the probability of occurrence of sperm competition because it guarantee the persistence of sperm in the females recently mated (Alcock 1994). In H. consors this behavior may represent an additional advantage diminishing the loss of potential de- 
scendants by sperm competition with other males. It also pose the relative importance of already mated females in a system were the appearance of a female is rare. This also diminished the harassment of mated females by other males and could be advantageous to the females (Waage 1979a; Conrad \& Pritchard 1990).

Emlen \& Oring (1977) pointed out that receptive female availability and possibility of resource defense by males are key factors in mating system evolution, and this was also emphasized particularly in Odonata (Conrad \& Pritchard 1992). The mating systems showed by H. consors is not based purely on active search for females, but on waiting for mating opportunities by males that cannot control oviposition resources. According to the Conrad \& Pritchard (1992) classification, $H$. consors fits to a non-resource system. Co-occurence between potential sexual partners in time and space in $H$. consors and the absence of courtship displays contribute to the maintenance of males with the ability to defend areas with better chance to intercept females. Movement patterns or the characteristics of females probably reveal its approximations to oviposition sites and facilitate its detection and capture. A female $H$. consors captured near stream margins may theoretically: (i) copulate and oviposit counting with male guard of the first mate that detect its approximation; (ii) space and copulate with other male or (iii) oviposit without male guard using stored sperm from previous copulation. The last option was possibly rare due to the negative effects of male harassment in these circumstances. It is expected that when the male physically keeps the female from other males, the oviposition sites are numerous and dispersed, males are weak fliers and female encounter is rare, Odonata males are not able to perform resource control strategies (Conrad \& Pritchard 1988; Conrad \& Pritchard 1992). H. consors mating system clearly fits to this classification. Comparing to other species that present this kind of mating system as Argia vivida (Conrad \& Pritchard 1988), we only observed mating at the ovipostion habitat and are no evidence of copulations at possible roosting sites. So far, there is no record of roosting site aggregation on these species which deserve further studies.

\section{ACKNOWLEDGEMENTS}

We thanks the Josiane B. dos Santos, Karina S. Furieri and Francisco C. C. Barreto for helped in field work and together with Sergio L. Mendes and Marcos V. C. Vital discussed an early version of this paper. We grateful also to Instituto de Defesa Agropecuária e Florestal (IDAF) of Espírito Santo state for providing logistic support for this study. Paulo De Marco Júnior also acknowledges the continuous funding by a CNPq grant.

\section{REFERENCES}

Alcock, J. 1979. Multiple matings in Calopteryx maculata (Odonata: Calopterygidae) and the advantage of non-contact guarding by males. Journal of Natural History 13: 439-446.
Alcock, J. 1982. Post-copulatory guarding by males of the damselfly Hetaerina vulnerata Selys (Odonata: Calopterygidae). Animal Behaviour 30: 99-107.

Alcock, J. 1987. The effects of experimental manipulation of resources on the behavior of two calopterygid damselflies that exhibit resourcedefense polygyny. Canadian Journal of Zoology 65: 2475-2482.

Alcock, J. 1994. Postinsemination associations between males and females in insects: the mate-guarding hypothesis. Annual Review of Entomology 39: 1-21.

Azevedo, C. O. \& H. S. Santos. 2000. Perfil da fauna de himenópteros parasitóides (Insecta, Hymenoptera) em uma área de Mata Atlântica da Reserva Biológica de Duas Bocas, Cariacica, ES, Brasil. Boletim do Museu de Biologia Professor Mello Leitão (Ser. Zool.) 11/12: 116-126.

Clausnitzer, V. 1998. Territorial behaviour of a rainforest dragonfly Notiothemis robertsi (Odonata: Libellulidae): proposed functions of specific behavioural patterns. Journal of Zoology 245: 121-127.

Conrad, K. F. \& G. Pritchard. 1988. The reproductive behavior of Argia vivida Hagen: an example of a female-control mating system (Zygoptera: Coenagrionidae). Odonatologica 17: 179-185.

Conrad, K. F. \& G. Pritchard. 1990. Pre-oviposition mate-guarding and mating behaviour of Argia vivida (Odonata: Coenagrionidae). Ecological Entomology 15: 363-370.

Conrad, K. F. \& G. Pritchard. 1992. An ecological classification of odonate mating systems: The relative influence of natural, inter- and intra-sexual selection on males. Biological Journal of the Linnean Society 45: 255-269.

Corbet,P. S. 1962. A biology of dragonflies. London, Witherby, 247 p.

Corbet, P. S. 1999. Dragonflies: behavior and ecology of Odonata. Ithaca, Comstock Publ. Assoc., 829 p.

Corbet, P. S. \& M. L. May. 2008. Fliers and perchers among Odonata: dichotomy or multidimensional continuum? A provisional reappraisal. International Journal of Odonatology 11: 155-171.

Cordoba-Aguilar, A. 1994a. Adult survival and movement in males of the damselfly Hetaerina cruentata (Odonata: Calopterygidae). Florida Entomologist 77: 256-264.

Cordoba-Aguilar, A. 1994b. Male substrate use in relation to age and size in Hetaerina cruentata (Rambur) (Zygoptera: Calopterigidae). Odonatologica 23: 399-403.

Cordoba-Aguilar, A. 1995. Male territorial tactics in the damselfly Hetaerina cruentata (Rambur) (Zygoptera: Calopterygidae). Odonatologica 24: 441-449.

Cordoba-Aguilar, A. 2001. Sperm displacement ability in the damselfly Calopteryx haemorrhoidalis asturica Ocharan: No effect of male age, territorial status, copulation duration and syn-copulatory behaviour (Zygoptera: Calopterygidae). Odonatologica 30: 375-380.

Cordoba-Aguilar, A.; G. Raihani; M. A. Serrano-Meneses \& J. ContrerasGarduno. 2009. The lek mating system of Hetaerina damselflies (Insecta: Calopterygidae). Behaviour 146: 189-207.

De Marco, P. 1998. The Amazonian Campina dragonfly assemblage: patterns in microhabitat use and behavior in a foraging habitat. Odonatologica 27: 239-248.

De Marco, P.; A. O. Latini \& D. C. Resende. 2005. Thermoregulatory constraints on behavior: patterns in a Neotropical dragonfly assemblage. Neotropical Entomology 34: 155-162.

De Marco, P.; A. O. Latini \& P. H. E. Ribeiro. 2002. Behavioural ecology of Erythemis plebeja (Burmeister) at a small pond in Southeastern Brazil (Anisoptera: Libellulidae). Odonatologica 31: 305-312.

De Marco, P. \& P. E. C. Peixoto. 2004. Population dynamics of Hetaerina rosea and its relationship to abiotic conditions (Zygoptera: Calopterygidae). Odonatologica 33: 17-25.

De Marco, P. \& D. C. Resende. 2002. Activity patterns and thermoregulation in a tropical dragonfly assemblage. Odonatologica 31: 129-138.

De Marco, P. \& M. V. C. Vital. 2008. Ecology of Tigriagrion aurantinigrum calvert in response to variations in environmental conditions (Zygoptera: Coenagrionidae). Odonatologica 37: 1-11.

DeBano, S. J. 1993. Territoriality in the dragonfly Libellula saturata Uhler: Mutual avoidance or resource defense? (Anisoptera: Libellulidae). Odonatologica 22: 431-441. 
Emlen, S. T. \& L. W. Oring. 1977. Ecology, sexual selection and the evolution of mating systems. Science 197: 215-223.

Ferreira-Peruquetti, P. \& P. De Marco. 2002. Efeito da alteração ambiental sobre comunidades de Odonata em riachos de Mata Atlântica de Minas Gerais, Brasil. Revista Brasileira de Zoologia 19: 317-327.

Fincke, O. M. 1997. Conflict resolution in the Odonata: Implications for understanding female mating patterns and female choice. Biological Journal of the Linnean Society 60: 201-220.

Fox, S. F. \& T. A. Baird. 1992. The dear enemy phenomenon in the collared lizard, Crotaphytus collaris with a cautionary note on experimental methodology. Animal Behaviour 44: 780-782.

Gribbin, S. D. \& D. J. Thompson. 1991. The effects of size and residency on territorial disputes and short-term mating success in the damselfly Pyrrhosoma nymphula (Sulzer) (Zygoptera: Coenagrionidae). Animal Behaviour 41: 689-695.

Hartung, M. 2002. Heteragrion palmichale spec. nov., a new damselfly from the Cordillera de la Costa, Venezuela (Zygoptera: Megapodagrionidae). Odonatologica 31: 187-191.

Hayashi, F. \& K. Tsuchiya. 2005. Functional association between female sperm storage organs and male sperm removal organs in calopterygid damselflies. Entomological Science 8: 245-252.

Henwood, K. 1975. Infrared transmittance as an alternative thermal strategy in the desert bettle Onymacris plana. Science 189: 993-994.

Higashi, K. \& S. Nomakuchi. 1997. Alternative mating tactics and aggressive male interactions in Mnais nawai Yamamoto (Zygoptera: Calopterygidae). Odonatologica 26: 159-169.

Hilfert-Ruppell, D. 1998. Temperature dependence of flight activity of odonata by ponds. Odonatologica 27: 45-59.

Irusta, J. B. \& A. Araujo. 2006. Reproductive behaviour of Diastatops obscura (Fabricius) in a riverine environment (Anisoptera: Libellulidae). Odonatologica 35: 289-295.

Jacobs, M. E. 1955. Studies on territorialism and sexual selection in dragonflies. Ecology 36: 566-586.

Johnson, C. 1964. The evolution of territoriality in the Odonata. Evolution 18: 89-92.

Lencioni, F. A. A. 2005. Damselflies of Brazil, an illustrated indentification guide: $\mathbf{I}$-The non-Coenagrionidae families. All Print Editora, São Paulo, Brazil, 324 p.

Machado, A. B. M.; G.A.B.Fonseca, R. B. Machado, L. M. S.Aguiar \& L. V. Lins, 1998. Livro Vermelho das espécies ameaçadas de extinção da fauna de Minas Gerais. Belo Horizonte, Fundação Biodiversitas, $608 \mathrm{p}$.

Marden, J. H. \& J. K. Waage. 1990. Escalated damselfly territorial contests are energetic wars of attrition. Animal Behaviour 39: 954-959.

May, M. L. 1976. Thermoregulation in adaptation to temperature in dragonflies (Odonata: Anisoptera). Ecological Monographs 46: 1-32.

May, M. L. 1977. Thermoregulation and reprodutive activity in tropical dragonflies of the genus Micrathyria. Ecology 58: 787-798.

May, M. L. 1991. Thermal adaptations of dragonflies, revisited. Advances in Odonatology 5: 71-88.

Meek, S. B. \& T. B. Herman. 1990. A comparison of the reproductive behaviors of three Calopteryx species (Odonata: Calopterygidae) in Nova Scotia (Canada). Canadian Journal of Zoology 68: 10-16.

Miller, A. K.; P. L. Miller \& M. T. Siva-Jothy. 1984. Pre-copulatory guarding and other aspects of reproductive behaviour in Sympetrum depressiusculum
(Selys) at rice fields in southern France (Anisoptera: Libellulidae). Odonatologica 13: 407-414.

Norma-Rashid, Y. 1999. Behavioural ecology of Tyriobapta torrida Kirby at the breeding and resting sites (Anisoptera: Libellulidae). Odonatologica 28: 139-150.

Novelo-Gutiérrez, R. 1987. Las nayades de Heteragrion albifrons, $H$. alienum y $H$. tricellulare (Odonata: Megapodagrionidae): su descripcion y habitos. Folia Entomologica Mexicana 73: 11-22.

Paulson, D. R. 1981. Anatomical modifications for displaying bright coloration in megapodagrionid and chlorocyphid dragonflies (Zygoptera). Odonatologica 10: 301-310.

Polcyn, D. M. 1994. Thermoregulation during summer activity in Mojave Desert dragonflies (Odonata: Anisoptera). Functional Ecology 8: 441449

Pratt, A. E. \& D. K. McLain. 2006. How dear is my enemy: Intruder-resident and resident-resident encounters in male sand fiddler crabs (Uca pugilator). Behaviour 143: 597-617.

Resende, D. C. \& P. De Marco. 2010. First description of reproductive behavior of the Amazonian damselfly Chalcopteryx rutilans (Rambur) (Odonata, Polythoridae). Revista Brasileira de Entomologia 54: 436440 .

Rizzini, C.T. 1979. Tratado de fitogeografia do Brasil. São Paulo, HUCITEC/Edusp, 375 p.

Samejima, Y. \& Y. Tsubaki. 2010. Body temperature and body size affect flight performance in a damselfly. Behavioral Ecology and Sociobiology 64: 685-692.

Santos, N. D. 1970. Contribuição ao conhecimento da fuana do estado da guanabara. 75 - Descrição de Heteragrion consors Selys, 1862 (Allotypus fêmea) (Odonata: Megapodagrionidae). Atas da Sociedade de Biologia do Rio De Janeiro 13: 149-151.

Shelly, T. E. 1982. Comparative foraging behavior of light- versus shadeseeking damselflies in a lowland neotropical forest (Odonata: Zygoptera). Physiological Zoology 55: 335-343.

Siva-Jothy, M. T. 1987. Variation in copulation duration and the resultant degree of sperm removal in Orthetrum cancellatum (L.) (Libellulidae: Odonata). Behavioral Ecology and Sociobiology 20: 147-151.

Temeles, E. J. 1994. The role of neighbours in territorial systems: when are they 'dear enemies'. Animal Behaviour 47: 339-350.

Tsubaki, Y.; Y. Samejima \& M. T. Siva-Jothy. 2010. Damselfly females prefer hot males: higher courtship success in males in sunspots. Behavioral Ecology and Sociobiology 64: 1547-1554.

Waage, J. K. 1979a. Adaptive significance of post-copulatory guarding of mates and non-mates by male Calopteryx maculata (Odonata). Behavioral Ecology and Sociobiology 6: 147-154.

Waage, J. K. 1979b. Dual function of the damselfly penis: sperm removal and transfer. Science 203: 916-918.

Waage, J. K. 1986. Evidence for widespread sperm displacement ability among Zygoptera (Odonata) and the means for predicting its presence. Biological Journal of the Linnean Society 28: 285-300.

Waage, J. K. 1988. Confusion over residency and the escalation of damselfly territorial disputes. Animal Behaviour 36: 586-595.

Wildermuth, H. 1991. Behaviour of Perithemis mooma Kirby at the oviposition site (Anisoptera: Libellulidae). Odonatologica 20: 471-478.

Wildermuth, H. 1994. Reproductive behaviour of Diastatops intensa Montgomery (Anisoptera: Libellulidae). Odonatologica 23: 183-191.

Received 12/11/2010; accepted 2/8/2011

Editor: Rodrigo Krüger 